\title{
DYNAMICS OF HUMAN URINE STORAGE IN THE EARLY PLANETARY BASE WASTESTREAM
}

\author{
Eric McLamore, Audra Morse, and W. Andrew Jackson \\ Texas Tech University, Lubbock, TX 79409, USA
}

\begin{abstract}
Although current proposed water recovery systems in space do not incorporate biotreatment technologies, research has indicated that bioprocessors (BP) may be a potential primary treatment technology in integrated advanced life support systems for long-duration space missions. Little data have been reported on the activity of nonacidified wastewater in the collection system prior to entering water recovery systems. These reactions are vital in accurately quantifying biosystem performance, mass balances, and microbial kinetics for bioprocessors operated on dynamic wastestreams. The bioavailable dissolved organic carbon and ammonium concentrations of storage tank grab samples may vary by up to $44 \pm 9 \%$ and $81 \pm 12 \%$, respectively, in a urine-containing wastestream. A model for quantifying the average rate of microbially based holding tank activity is presented. A brief enzymatic inhibition study indicated that surfactants contained within the wastestream may be inhibiting feed tank urease activity, causing the organic carbon and ammonium variability. The aim of this research is to quantify storage tank reactions so that future bioprocessor models reflect only the activity occurring within the BP, and not that of the feed tank. Although microbially active collection vessels may be a consideration for long-duration missions, their activity should be modeled independently to avoid the "black box" approach to modeling BP dynamics. The results will aid future researchers in operating biosystems on urine-gray water wastestreams.
\end{abstract}

Key words: Human urine; Bioavailable organic carbon; Urea hydrolysis; Urease inhibition; Surfactant

\section{INTRODUCTION}

Current research is being conducted on various downscaled models $(1 / 20)$ of the integrated water recovery system (WRS) $(6,11,16,17)$ at NASA's Johnson Space Center (3). The feed solution simulates the concentration of constituents in the waste collection system used during the early planetarybased (EPB) integrated WRS study at JSC $(3,27,32)$. The EPB feed solution consists of a modified version of Pert Plus ${ }^{\circledR}$ for Kids "minus" (PPKm), nonpretreated urine, simulated cabin humidity condensate (HC), and deionized distilled water (DDI) as makeup water. The "minus" in PPK signifies that the surfactant recipe represents Pert Plus for Kids less the dyes, scents, and additives. The natural variability of human urine and activity associated with com- mon biosystem feed tanks has caused high standard deviations in influent data, significantly affecting bioprocessor removal data $(11,16)$. Research on this system employed grab sample techniques at various locations within the system, with the majority of the samples being taken from influent and effluent collection vessels. Some of the problems encountered included inaccurate influent ammonium $\left(\mathrm{NH}_{4}^{+}\right)$and dissolved organic carbon (DOC) concentrations. System operation alterations (such as 24-h storage of urine) were made to correct this problem, but the 24$\mathrm{h}$ high variability of ammonia (from 120 to $630 \mathrm{mg}$ $\mathrm{N} / \mathrm{L}$ ) and DOC (from 105 to $805 \mathrm{mg} \mathrm{DOC} / \mathrm{L}$ ) in the feed tank persisted. Bioavailable DOC should be estimated for similar wastestreams as the urine within the EPB stream comprises an average of $75 \%$ of the DOC, with the remaining $25 \%$ being contributed by 
surfactant and HC. Consideration of feed tank activity in systems of this type is vital when reporting accurate data because influent concentrations can vary drastically between grab samples.

It was assumed that the majority of the feed tank activity was hydrolytic in nature and that urea is the most prevalent of the hydrolytically susceptible compounds in the EPB wastestream (by mass). It was initially assumed that urea hydrolysis would be complete within the typical 24-h feed tank holding period as urea was rapidly decomposed during the integrated WRS experiments at JSC $(3,27)$. Research and studies by Strayer et al. (25) and the U.S. EPA (26) indicated that the time required for complete urea degradation during bench-scale studies may be significantly longer that the reported values of 1-5 min, depending on the wastestream. During the first 2 years of operation of the TTU-WRS, a $\mathrm{pH}$ increase of $0.63 \pm 0.27$, a DOC decrease of $40 \pm 22 \mathrm{mg} \mathrm{DOC/}$ $\mathrm{L}$, and an $\mathrm{NH}_{4}^{+}$increase of $50 \pm 31 \mathrm{mg} \mathrm{N} / \mathrm{L}$ in the feed tank was observed within a $24-\mathrm{h}$ period $(11,16)$. Inaccurate system influent data affect reported values for system mass balances, reactor removal efficiency, and microbial kinetics. Characterization of feed tank reactions during the design phase will arm researchers with a comprehensive knowledge of expected biosystem performance and establish best management practices for reporting bioprocessor removal rates.

The purpose of this research was to: 1) verify that the majority of the activity within the feed tank was due to urea hydrolysis, 2) establish a general equation for estimating bioavailable influent organic carbon, and 3) quantify the rate of urease inhibition by PPKm and $\mathrm{HC}$ within the EPB wastestream. This was accomplished by two different sets of experiments. The first set of experiments was a general overview of all biochemical feed tank activity and the second set of experiments was a detailed analysis of urease inhibition.

Although urea is an organic compound, the carbonaceous product of urea hydrolysis $\left(\mathrm{CO}_{2}\right)$ is inorganic. When analyzing BP samples using the high-temperature combustion (HTC) method, this may lead to an overestimation in DOC removal rates. TC analyzers using both the total inorganic carbon/total carbon (TIC/ TC) and total carbon/total organic carbon (TC/TOC) methods detect combusted urea as $\mathrm{CO}_{2}$ and report the value as organic carbon (false positive). Although the byproducts of urea hydrolysis are used by autotrophic microbes in the bioprocessor (BP), the concern of this article is the overestimation of bioavailable DOC when using the HTC method in the presence of urea. Overestimation of the useable DOC concentration leads to false potential nitrogen removal estimations (i.e., denitrification) and inflated experimental DOC removal rates. Though other nitrogenous compounds in urine are susceptible to hydrolysis reactions that produce $\mathrm{NH}_{4}{ }^{+}$, only urea hydrolysis significantly produces the noted "false positive" influent DOC values. Techniques such as the commonly used nonpurgeable organic carbon (NPOC) method are intended to strip inorganic carbon prior to high-temperature combustion, and merely inhibit urease activity in samples containing urea. Such methods do not solve the overestimation of DOC in samples containing significant urea.

It was assumed that the carbonaceous byproducts of combusted urea in urine are isocyanic acid, carbamic acid, and eventually $\mathrm{CO}_{2}(1,5)$, though other combustion pathways have been proposed $(2,7)$. Table 1 indicates the approximate nitrogenous and carbonaceous hydrolytic product concentrations for urea, creatinine, and hippuric acid based on average concentrations taken from Putnam et al. (18), Verostko et al. (27), and Webb et al. (29).

This set of experiments will aid in increasing the accuracy of future bench-scale biosystem mass balances and analysis. Mass balances will become vital as terrestrial-tested biosystems reach higher technology readiness levels and prepare for in-flight validation. Microbially active feed tanks for benchscale systems using raw urine may operate more as pseudobioprocessors than holding vessels. These dynamics should be accounted for if a possibility

Table 1. Estimated Hydrolytic Product Concentrations for Some Major Urine Compounds

\begin{tabular}{lcc}
\hline Compound & $\begin{array}{c}\text { Nitrogenous Product } \\
\text { Concentration } \\
(\mathrm{mg} \mathrm{N} / \mathrm{L})\end{array}$ & $\begin{array}{c}\text { Carbonaceous Product } \\
\text { Concentration } \\
(\mathrm{mg} \mathrm{C} / \mathrm{L})\end{array}$ \\
\hline Urea & 8026 & 2675 \\
Creatinine & 2070 & 190 \\
Hippuric acid & 90 & 120 \\
\hline
\end{tabular}


of inhibition by the presence of PPKm and/or HC may exist.

\section{MATERIALS AND METHODS}

Two different sets of experiments were conducted to analyze feed tank reactions and aid in developing biosystems for the EPB wastestream. The experimental outlines are presented below.

\section{Experiment Set \#1: Determination of Bioavailable DOC}

The first set of experiments was a comprehensive analysis considering urea hydrolysis. The purpose of this set of experiments was to develop a method to estimate the average bioavailable DOC concentration for a dynamic wastestream. The experiment employed three sterile feed tanks and three microbially active feed tanks. Feed tanks were assumed to be microbial active following 500 days of continuous operation and a noted visual increase in biosolids concentration.

Sterile feed tanks were autoclaved and transferred to a sterile anaerobic chamber for all experiments. Feed was formulated by preparing $6.0 \mathrm{~L}$ of feed $(6,11,16,17)$ and adding $2.0 \mathrm{~L}$ of feed to each tank. For further details on the PPKm see Rector et al. (20) and Sharvelle et al. (22). Details on the composition of the HC may be found in Campbell et al. (3) and Verostko et al. (27). The relative concentrations of typical compounds found in urine are presented in Wydeven and Golub (32). The feed tanks were covered with foil and sealed. Each feed tank was equipped with a gas trap to evaluate $\mathrm{NH}_{4}^{+}$stripping. The analyses were conducted over a 140 -h period to guarantee completion of the major enzymatic activity within the tank. The detention time of feed in the tank is not expected longer than $24 \mathrm{~h}$, but past research indicated that the maximum time required to complete all activity within the feed tank was approximately $60 \mathrm{~h}$ (unpublished data).

Feed tank samples were collected every $6 \mathrm{~h}$ and tested for $\mathrm{pH}$ and dissolved oxygen (DO). The remaining sample was filtered ( $<0.45$ micron) and tested for total nitrogen ( $\mathrm{TN}$ as $\mathrm{mg} \mathrm{N} / \mathrm{L}$ ), $\mathrm{NO}_{x}-\mathrm{N}$, $\mathrm{NH}_{4}^{+}-\mathrm{N}$, and DOC. The $\mathrm{NH}_{4}^{+}, \mathrm{pH}$, and temperature were analyzed using a ROSS probe (Thermo Orion model 8102-BN) and Thermo Orion $\mathrm{pH}$ meter (model 250A). DO samples were analyzed using a DO probe (Thermo Orion model 9708) and pH/ORP meter (IQ Scientific, Carlsbad, CA). $\mathrm{NO}_{2}-\mathrm{N}$, and $\mathrm{NO}_{3}-\mathrm{N}$ samples were analyzed using ion chromatography (DX-600 Dionex, USA). The TN and DOC samples were analyzed using a Shimadzu analyzer (Japan). DOC was determined using the NPOC HTC method outlined by Shimadzu. This method involved autoaddition of hydrochloric acid and nitrogen purging of inorganic carbon (as $\mathrm{CO}_{2}$ ) prior to combustion. Only DOC concentration values are reported herein. All sample handling procedures were followed as outlined in Standard Methods.

The total organic nitrogen concentration was calculated by subtracting the summation of measured inorganic nitrogen species from the measured $\mathrm{TN}$ $\mathrm{N}$. The average time required to complete urea hydrolysis for a typical feed solution was assumed to be complete when the TN concentration equaled the inorganic nitrogen $\left(\mathrm{NH}_{4}-\mathrm{N}+\mathrm{NO}_{x}-\mathrm{N}\right)$ concentration (implying negligible organic nitrogen exists). A general equation to predict heterotrophically bioavailable DOC was then developed using initial feed tank TN$\mathrm{N}, \mathrm{NH}_{4}{ }^{+}-\mathrm{N}, \mathrm{NO}_{\mathrm{x}}$, and $\mathrm{DOC}$ values.

\section{Experiment Set \#2: Urease Inhibition}

The second set of experiments was conducted to determine if PPKm surfactants and/or HC in the EPB wastestream reduced the urease activity. The two main surfactants in PPKm (sodium laureth sulfate and disodium cocoamphodiacetate) and the HC mixture were investigated. Following the procedures outlined in Fidaleo and Lavecchia (4) and Voet et al. (28), a noncompetitive (mixed) mechanism was assumed for urease inhibition and the data were analyzed by the initial-rate method. This model is presented in Figure 1, where:

$E=$ enzyme concentration $(\mathrm{mg} / \mathrm{L})$

$I=$ inhibitor concentration $(\mathrm{mg} / \mathrm{L})$

$S=$ substrate concentration $(\mathrm{mg} / \mathrm{L})$

$E I=$ enzyme-inhibitor complex $(\mathrm{mg} / \mathrm{L})$

$E S=$ enzyme-substrate complex $(\mathrm{mg} / \mathrm{L})$

$E S I=$ enzyme-inhibitor-substrate complex $(\mathrm{mg} / \mathrm{L})$

$P=$ product concentration $(\mathrm{mg} / \mathrm{L})$

$K_{i}$ and $+\mathrm{Ii}>=$ dissociation constants $\left(\mathrm{sec}^{-1}\right)$

$k=$ enzymatic rate constants $\left(\mathrm{sec}^{-1}\right)$. 


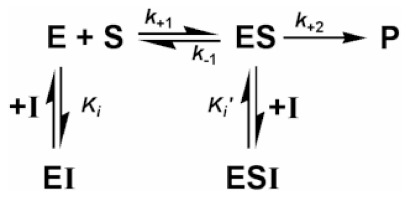

Figure 1. Mixed inhibition kinetic model (28).

The model describing noncompetitive (mixed) inhibition typically refers to both enzyme and enzymesubstrate complex binding by the inhibitor. The maximum reaction velocity $\left(v_{\max }\right)$, Michaelis-Menton $\left(K_{\mathrm{m}}\right)$, $K_{\mathrm{I}}$, and $K_{\mathrm{I}}$ constants were determined in the absence and presence of surfactants and/or HC, where the $K_{\mathrm{m}}$ is defined as: $\left(k-1+k_{2}\right) / k_{1}$. The inhibition constants $\left(K_{\mathrm{I}}=[I] / \gamma-1\right.$ and $\left.K_{\mathrm{I}^{\prime}}=[I] / \delta-1\right)$ were determined by Lineweaver-Burke plots. The equation defining the reaction velocity is (28):

$$
v_{o}=\frac{v_{\max }[S]}{\alpha K_{m}+\delta[S]}
$$

where

$v_{\mathrm{o}}=$ initial reaction velocity $(\mathrm{mM} / \mathrm{s})$

$v_{\max }=$ maximum reaction velocity $(\mathrm{mM} / \mathrm{s})$

$\alpha=$ inhibition factor $\left(=1+[I] / K_{\mathrm{I}}\right)$

$\delta=$ mixed inhibition factor $\left(=1+[I] / K_{\mathrm{I}^{\prime}}\right)$.

Following common procedure, the enzyme and inhibitor concentrations were constant while the substrate concentration varied to determine the value of $K_{\mathrm{m}}$. Each experiment was conducted in triplicate using substrate concentrations of 50, 100, 150, and 200 ppm urea (purity 98.0\%, Sigma Aldrich Chem. Co., St. Louis, MO). Lyophilized and chromatographically purified powder jack bean urease (Canavalia ensiformis, EC 3.5.1.5) was used throughout the experiments. Preliminary experiments were conducted using $0.05,0.10,0.25,0.50,1.00,2.00,2.50$, and 3.00 $\mathrm{mg} / \mathrm{L}$ urease to ensure that the urease value was adequate. Fidaleo and Lavecchia (4) noted that specific urease activity remained constant and no protein denaturation occurred up to urease concentrations of $200 \mathrm{mg} / \mathrm{L}$ urease. The final value chosen for the experiments was $1.00 \mathrm{mg} / \mathrm{L}$ urease. This gave urease/ urea ratios from 0.005 to 0.020 urease/urea $(\mathrm{g} / \mathrm{g})$, which falls within the typical range used by others $(8,10)$. PPKm (1.39 mg-PPKm/L-DDI) and HC $(0.71$
mg-HC/L-DDI) concentrations were constant, representing those typical to the EPB wastestream. The appropriate amount of substrate, PPKm, and HC was simultaneously added to 150 -ml narrow-neck bottles and each experiment was begun (time zero). Table 2 presents a matrix for the set of experiments.

Samples were collected every $5 \mathrm{~min}$ and placed in preacidified bottles $\left(\mathrm{H}_{2} \mathrm{SO}_{4}\right)$ to be tested for $\mathrm{NH}_{4}{ }^{+} \mathrm{N}$ or DOC (acidified with $\mathrm{HCl}^{-}$). The temperature throughout the enzyme kinetic studies was constant at $24.8 \pm 0.1^{\circ} \mathrm{C}$.

\section{RESULTS}

The results of both sets of experiments are presented below. The first set of experiments was conducted to establish a method of estimating bioavailable DOC and the second set of experiments examined some possible mechanisms of urease inhibition. The intent of this article is not to promote urea hydrolysis within microbially active holding vessels, but rather to provide biosystems researchers with a tool for accurately simulating real-world BP loading rates. This is particularly relevant for influent-effluent bioprocessor nitrogenous and/or carbonaceous data, or systems that contain significant concentrations of urea.

\section{Experiment Set \#1: Bioavailable DOC}

For brevity, complete results comparing the microbially active and sterile feed tanks are not shown; as was expected the active feed tanks were more biologically active than the sterile tanks (12). The total $\mathrm{pH}$ increase was $2.32 \pm 0.18$ over a 140 -h period; it was assumed that the majority of the $\mathrm{pH}$ increase was due to release of $\mathrm{OH}^{-}$during the hy-

Table 2. Urease Inhibition Experimental Matrix

\begin{tabular}{lccc}
\hline Test No. & $\begin{array}{c}\text { Substrate } \\
\text { Concentration } \\
(\mathrm{mg} / \mathrm{L} \text { Urea) }\end{array}$ & $\begin{array}{c}\text { PPKm } \\
\text { (mg PPKm/L } \\
\text { Waste) }\end{array}$ & $\begin{array}{c}\mathrm{HC} \\
\text { (mg HC/L } \\
\text { Waste) }\end{array}$ \\
\hline 1 & $50,100,150,200$ & 0 & 0 \\
2 & $50,100,150,200$ & 1.39 & 0 \\
3 & $50,100,150,200$ & 0 & 0.71 \\
4 & $50,100,150,200$ & 1.39 & 0.71 \\
\hline
\end{tabular}


drolysis of urea. Ammonia stripping within the feed tanks was negligible (the maximum ammonia concentration in the gas traps was $1.32 \pm 0.30 \mathrm{mg} \mathrm{N} / \mathrm{L}$ ) and the TN concentration did not significantly change in any of the feed tanks $(\Delta \mathrm{TN}=-19.5 \pm 8.0$ $\mathrm{mg} \mathrm{N} / \mathrm{L}$ ).

Depending on the time of the grab sample, the apparent bioavailable DOC decrease $(143 \pm 32 \mathrm{mg}$ DOC/L) was significant (Fig. 2). The progress curve in Figure 2 implies a maximum influent DOC overestimation of $53 \%$. The apparent feed tank DOC decrease was due to the combustion of urea within the Shimadzu analyzer and was not true biodegradation of DOC within the feed tank. During the first set of experiments it was noted that the time for complete hydrolysis of urea $(61 \pm 3 \mathrm{~h})$ within the feed tanks was much longer than the expected $24 \mathrm{~h}$. The DO decrease during the first set of experiments was $4.13 \pm 0.58 \mathrm{mg} / \mathrm{L} \mathrm{DO} /$ tank. Theoretically, $0.27 \mathrm{~g} \mathrm{DO} /$ $\mathrm{g}$ urea is required for complete hydrolysis in aquatic environments at $20^{\circ} \mathrm{C}(26)$.

According to urea hydrolysis stoichiometry, $2 \mathrm{~mol}$ of ammonia is produced per mole of urea hydrolyzed (Equation 2). Assuming no other organic compounds in urine significantly contribute to the "false-positive" DOC, the total change in DOC ( $\mathrm{mmol} \mathrm{DOC/L})$ due to hydrolytic activity in the feed tank is theoretically equal to the number of moles of organic nitrogen $(\mathrm{mmol}$ urea/L) in the feed. Although other compounds contribute to $\mathrm{NH}_{4}^{+}$production in the feed tank, only urea contributes to both $\mathrm{NH}_{4}^{+}$production and "false DOC" production. This assumption was verified by observing the increase in $\mathrm{NH}_{4}-\mathrm{N}$ within each feed tank. The experimental number of moles of ammonia produced per mole of urea hydrolyzed for each feed tank $\left(1.8 \pm 0.7 \mathrm{~mol} \mathrm{NH}_{4} / \mathrm{mol} \mathrm{DOC}\right)$ was near the expected value of 2 .

$$
\begin{gathered}
\mathrm{CO}_{2}\left(\mathrm{NH}_{2}\right)+\mathrm{HOH}+\text { urease } \rightarrow \\
\mathrm{H}_{2} \mathrm{NCOOHNH}_{4} \rightarrow 2 \mathrm{NH}_{3}+\mathrm{CO}_{2}+\mathrm{H}_{2} \mathrm{O}
\end{gathered}
$$

The data from the first set of experiments verified that the majority of the feed tank activity was due to urea hydrolysis. The following set of equations was then used to estimate the bioavailable DOC within a fresh batch of EPB feed using initial feed tank TN, DOC, $\mathrm{NH}_{4}{ }^{+}-\mathrm{N}$ and $\mathrm{NO}_{x}-\mathrm{N}$ values. The 0.9 in Equation (3) was determined by averaging the amount of urea/total organic nitrogen in 72 urine samples ( $\mathrm{SD} \pm 0.04)$. Details concerning the validation of the set of equations below may be found in McLamore (12).

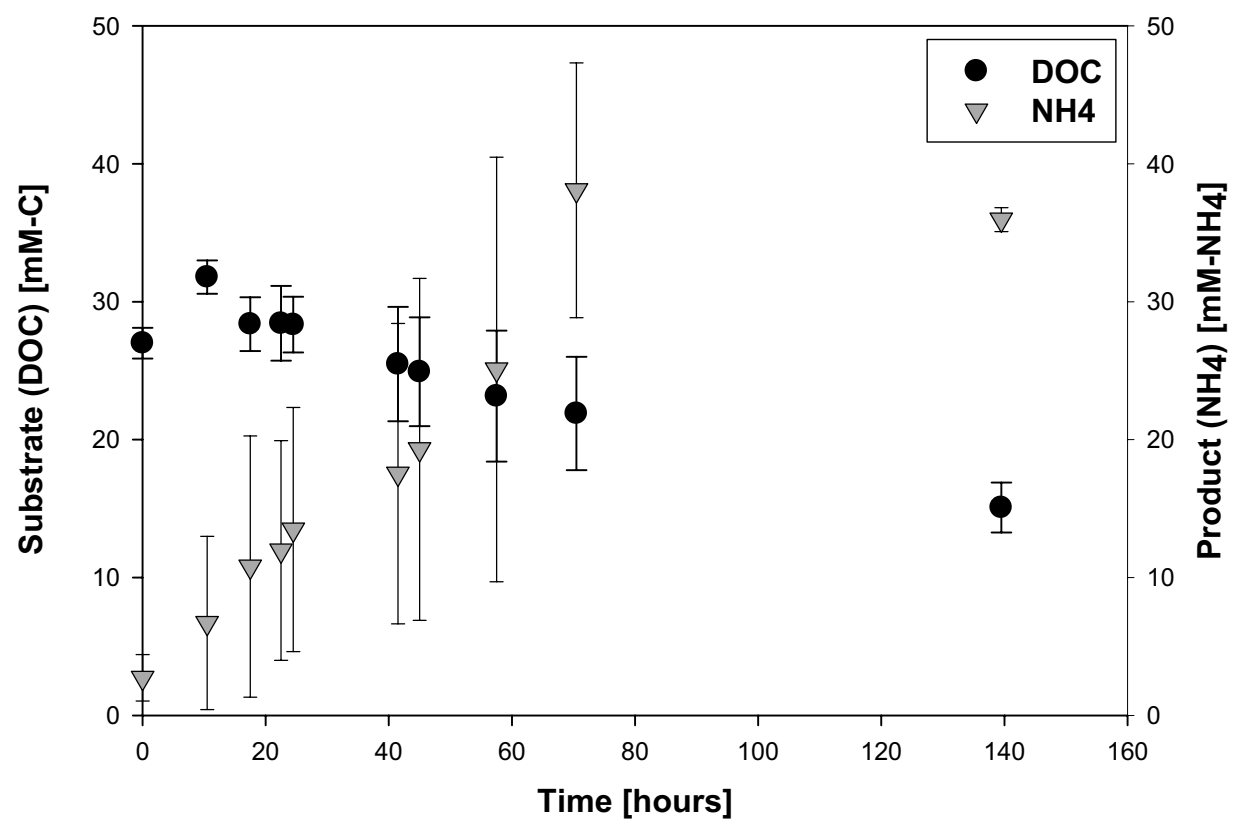

Figure 2. Feed tank progress curve [circles represent average concentration $(n=3)$ and error bars represent $\pm 1 \mathrm{SD}]$. 


$$
\begin{gathered}
\left(\mathrm{DOC}_{\text {urea }}\right)_{i}=0.9\left[\mathrm{TN}_{i}-\left(\mathrm{NH}_{4}^{+}-\mathrm{NO}_{x}\right)_{i}\right]^{*} \mathrm{C} \\
\mathrm{DOC}_{\text {bioavalable }}=\mathrm{DOC}_{\text {initial }}-\left(\mathrm{DOC}_{\text {urea }}\right)_{i}
\end{gathered}
$$

where

$\left(\mathrm{DOC}_{\text {urea }}\right)_{i}=$ initial DOC concentration contributed by urea $(\mathrm{mg} / \mathrm{L} \mathrm{C})$

$\mathrm{DOC}_{\text {bioavailable }}=\mathrm{DOC}$ available for heterotrophic degradation $(\mathrm{mg} / \mathrm{L} \mathrm{C})$

$\mathrm{DOC}_{\text {initial }}=$ total initial DOC concentration $(\mathrm{mg} / \mathrm{L} \mathrm{C})$

$\mathrm{TN}_{i}=$ initial $\mathrm{TN}$ concentration $(\mathrm{mg} / \mathrm{L} \mathrm{N})$

$\left(\mathrm{NH}_{4}^{+}\right)_{i}=$ initial ammonium concentration $(\mathrm{mg} / \mathrm{L} \mathrm{N})$

$\left(\mathrm{NO}_{x}\right)_{i}=$ initial $\mathrm{NO}_{x}$ concentration $(\mathrm{mg} / \mathrm{L} \mathrm{N})$

$\mathrm{C}=$ unit conversion factor $(=1.7 \mathrm{mM}$ urea $\mathrm{DOC} / \mathrm{mM}$ urea $\mathrm{N}$ ).

\section{Experiment Set \#2: Urease Inhibition}

The extended period of time required for complete urea hydrolysis in the first set of experiments prompted a second set of experiments to be conducted. The purpose of the second set of experiments was to examine the inhibition of urease by PPKm and HC at typical EPB concentrations. Typical Lineweaver-Burke plots for each experiment using $1.0 \mathrm{ppm}$ urease are presented below. Note that the error bars in Figure 3 are extremely small, as others have found in similar experiments (10).

Figure 3 indicates that the $\mathrm{HC}$ may have had a very small inhibitory effect on urease activity, but the PPKm exhibited a significant inhibitory effect. To further express these results, the Michaelis-Menton constant $\left(K_{\mathrm{m}}\right)$, competitive inhibition constant $\left(K_{\mathrm{I}}\right)$, and uncompetitive inhibition constant $\left(K_{\mathrm{I}}\right)$ for each experiment is presented in Table 3.

The $K_{\mathrm{m}}$ value for urea $(5.51 \pm 0.97)$ was near $K_{m}$ values $(3.21 \pm 0.36)$ obtained by Fidaleo and Lavecchia (4) for $25^{\circ} \mathrm{C}$. Constants were determined using Lineweaver-Burke plots for each experiment. The enzyme model implies that PPKm inhibits urease activity both by competing for the active site and a site distal (or proximal) to the active site, the majority of the competition being the latter. This is evident by the increasing kinetic constants during the experiments where PPKm was present. The HC had little to no effect on urease activity. Binding at a site other than the enzyme's active site typically distorts the active site and renders the enzyme catalytically inactive. The precise mechanism of inhibition was not determined and further analysis should be conducted to quantify the mode and action of urea hydrolysis inhibition within the EPB holding vessels.

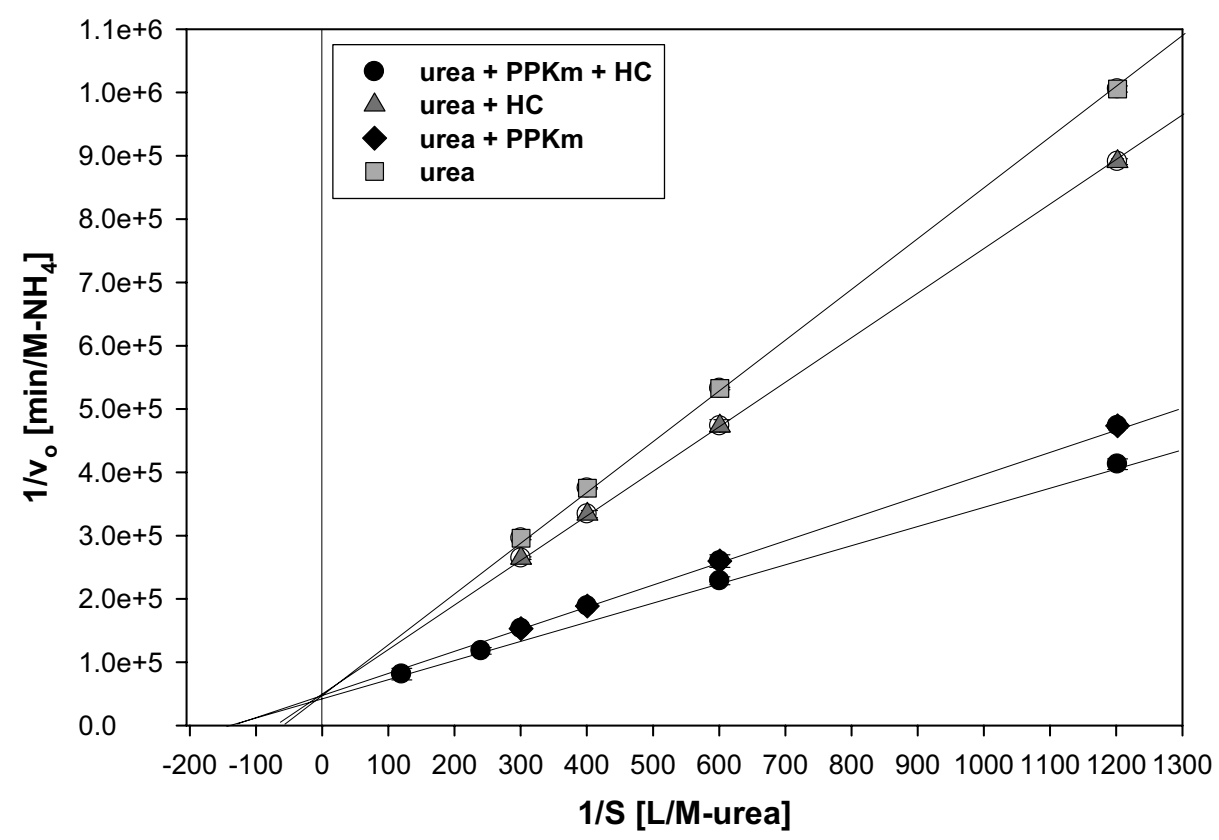

Figure 3. Urea-urease kinetics and enzyme inhibition [symbols represent averages $(n=3)$ and error bars represent $\pm 1 \mathrm{SD}]$. 
Table 3. Mixed Inhibition of Urease

\begin{tabular}{lrcc}
\hline $\begin{array}{l}\text { Urease } \\
\text { Experiment }\end{array}$ & $\begin{array}{c}K_{\mathrm{m}} \\
(\mathrm{mM} \text { Urea })\end{array}$ & $\begin{array}{c}K_{\mathrm{I}} \\
{\left[(\mathrm{mM} \mathrm{PPKm}) \times 10^{-2}\right]}\end{array}$ & $\begin{array}{c}K_{\mathrm{I}^{\prime}} \\
{\left[(\mathrm{mM} \mathrm{HC}) \times 10^{-2}\right]}\end{array}$ \\
\hline Urea & $5.51 \pm 0.97$ & - & - \\
Urease + PPKm & $11.11 \pm 1.61$ & $5.28 \pm 0.06$ & $1.41 \pm 0.01$ \\
Urease + HC & $5.92 \pm 1.54$ & $38.5 \pm 0.13$ & $8.20 \pm 0.03$ \\
Urease + PPKm + HC & $14.51 \pm 1.90$ & $4.70 \pm 0.09$ & $1.03 \pm 0.02$ \\
\hline
\end{tabular}

Quantification of urease activity within wastewater collection systems is vital in conducting biosystems mass balances and predicting microbial kinetics in systems with a closed-loop nature.

\section{DISCUSSION}

Regardless of the type of system used on board future space missions, hydrolytic activity within wastewater collection systems is unavoidable (unless acidified). In-flight acidification of raw liquid waste would require addition of excess chemicals both upstream and downstream of biosystems and may not be economically favorable for long-duration space travel if biological systems are used. Feed tank acidification may not affect overall BP performance and would inhibit precipitate formation (i.e., struvite). However, accurately simulating realistic loading rates for terrestrial dynamic wastestreams may prove difficult when using raw urine. Synthetic wastestreams simulate constituent concentrations at a given time, but cannot accurately simulate the variation in dynamic wastestreams. With the given EPB wastestream, the efficiency of the biosystems within the WRS depends largely on carbon availability, reflected by the high concentrations of nitrogenous species in the effluent $(6,11,16)$. As technology readiness levels progress, detailed analyses (such as mass balances and microbial kinetics) become increasingly important in biosystems design and determination of the precise bioavailable DOC concentration for a wastestream is fundamental in optimizing these parameters.

Holding and/or collection strategies may include urine separation (30), preacidification, struvite removal (31), and others, which will affect BP loading rates and potential biosystem efficiency. Feed tank studies aid in defining dynamic wastestream loading rates. Research has indicated a considerable difference between the feed tanks from the pilot plant system at NASA-JSC and the bench-scale systems at Texas Tech University (TTU) (Melissa Campbell, personal communication). This difference could have been due to many reasons including (but not limited to): the relatively large capacity of the waste collection system at JSC (and therefore relative mass of urease) or the shower used at JSC to collect make-up water as human skin contains highly active urease $(8,10,13,14)$. In addition, the accumulation of urea hydrolysis intermediates may have had a relatively large impact on urease activity in the bench-scale system when compared to the NASA-JSC system. Webb (29 noted $\mathrm{pH}$-dependent noncompetitive urease inhibition by intermediates formed during urea hydrolysis, namely methylurea and oxyurea. Further research is required to fully understand the hydrolytic activity of the compounds in urine-containing wastestreams for terrestrial bench-scale biosystem feed tanks and/or in-flight waste holding vessels.

Significant precipitation has been noted within the biosystem feed tanks at TTU. Mobley and Hausinger (14) indicated that precipitate is formed within human and synthetic urine in the presence of urease due to the development of alkalinity, supersaturation, and consequent encrustation of calcium and magnesium. Stegmayr and Stegmayr (24) noted a decrease of soluble calcium and magnesium in urine, which was consistent with precipitate formed in the presence of urease. Thus, it was assumed that precipitate in the bottom of the feed tanks was a struvite-like compound (based on $\mathrm{pH}$ values). It may be possible to take advantage of such precipitates (such as struvite) for utilization in other life support systems. Further research should be conducted to quantify all of the relevant biochemical feed tank activity for bench-scale systems. 


\section{CONCLUSION}

The activity within a feed (holding) tank operating on an EPB wastestream was investigated. The purpose of the analysis was to develop a method for estimating influent bioavailable dissolved organic carbon concentrations and begin examining possible inhibitors of urease activity. Analyzing feed tank activity allowed researchers to quantify true nitrogen and carbon loading rates for bench-scale bioprocessors during normal operation, aiding in system mass balances, sizing of bioreactors, and increasing the accuracy of microbial kinetics. The experiments also investigated the activity of a urea-urease-inhibitor complex. Results indicated the surfactants in the wastestream were the major inhibitor of urease activity. The primary form of inhibition was distortion of the active site on urease. Other compounds within the wastestream may increase the extent of inhibition and further research should be conducted concerning this matter.

Acknowledgements - The authors would like to thank the Center for Space Sciences at Texas Tech University for funding this research and the Advanced Life Support Systems research team at Johnson Space Center, namely Martin P. Olson and Daniel Haddock for chemical analyses. An addition thanks goes out to Dr. Paul Par\&eacute; at TTU for help with kinetic studies.

\section{BIOGRAPHICAL NOTES}

Eric McLamore is a graduate student/research assistant. He received his B.S. (2002) in Civil Engineering and an M.S. (2004) in Civil Engineering from Texas Tech University. Eric is currently a research assistant working on his Ph.D. at Purdue University, and will graduate in May 2008. Research experience includes design, construction, operation, and analysis of membrane-aerated and liquid/gas bioprocessors designed for microgravity conditions. Current research includes investigation of boundary layer biofilm dynamics using novel self-referencing microelectrodes, multicomponent two-phase fluid dynamics, graywater reuse and sustainable systems, and biological processor design for closed-loop aquaculture applications.

Dr. Audra Morse is an assistant professor at Texas Tech University, where she received her B.S. (1999) and M. (1999) in Environmental Engineering and Ph.D. (2003) in Civil Engineering. Dr. Morse has investigated the fate of pharmaceuticals and hormones in a bench-scale wastewater treatment system under a NASA-related project funded by the Center for Space Sciences at Texas Tech University. In addition, she has evaluated the benefits of using membrane-aerated biological reactors as a nitrifying reactor in space and for the biological removal of perchlorate. Dr. Morse's curriculum vitae may be seen at the following web address: http://www.faculty.ce.ttu.edu/amorse

Dr. Andrew Jackson received his Ph.D. (1996) and M.S. (1993) in Environmental Engineering from Louisiana State University and a B.S. (1990) in Biology from Rhodes College. Dr. Jackson's general field of expertise is related to the remediation of hazardous wastes in the surface and subsurface. His research has involved a wide variety of contaminants including perchlorate, chlorinated solvents, crude Oil, BTEX, pesticides, pharmaceuticals, and other anthropogenic compounds. His work includes a variety of field sites and environmental conditions from salt marshes to Superfund sites. In addition, his work involves longterm recycling of drinking water, including treatment, optimization, and fate of persistence of undesirable chemical compounds. He serves as the faculty advisor to the Society of Environmental Professionals and to the annual team of students who compete in the WERC national environmental design contest. Dr. Jackson's curriculum vitae may be seen at the following web address: http://www6.tltc.ttu.edu/jackson/JACKSON'S\%20VITA_ 050704\%20(4).doc

\section{REFERENCES}

1. Alzueta, M. U.; Bilbao, R.; Millera, A.; Oliva, M.; Ibanez, J. C. Impact of new findings concerning urea thermal decomposition on the modeling of the urea-SNCR process. Energy Fuels 14(2)509-510; 2000.

2. Bilbao, R.; Oliva, M.; Ibañez, J. C.; Zapater, A.; Millera, A.; Alzueta, M. U. 9th International Conference on Coal Science, Essen, 1997:1863-1866.

3. Campbell, M.; Finger, B.; Verostko, C.; Wines, K. R.; Pariani, G.; Pickering, K. D. Integrated water recovery systems test. 33rd International Conference on Environmental Systems (ICES). Bayshore Resort \& Marina. Vancouver, B.C., Canada, July 7-10, 2003.

4. Fidaleo, M.; Lavecchia, R. Kinetic study of enzymatic urea hydrolysis in the $\mathrm{pH}$ range 4-9. Chem. Biochem. Eng. Q. 17(4):311-318; 2003.

5. Gentamann, A. M.; Caton, J. A. (2001). Decomposition and oxidation of a urea-water solution as used in selective noncatalyic removal (SNCR) processes. 2nd Joint Meeting of the United States Sections of the Combustion Institute, Spring Technical Conference, Oakland, CA; 2001.

6. Jackson, A.; Morse, A.; McLamore, E.; Collins, G. (2004). Effect of recycle ratio on the performance of biological water recovery system (Paper \# 2004-01-2468). 34th International Conference on Environmental Systems (ICES), Colorado Springs, CO; 2004.

7. Jødal, M.; Nielsen, C.; Hulgaard, T.; Dam-Johansen, K. Twenty-Third Symposium (International) on Combustion, The Combustion Institute, Pittsburgh, PA; 1990:237-243. 
8. Kiss, S.; Simihaian, M. (2002). Improving efficiency of urea fertilizers by inhibition of soil urease activity. Environmental Protection Agency, Department of Environmental Management, Romania: Kluwer Academic Publishers.

9. Krajewska, B.; Zaborska, W. (1999). The effect of phosphate buffer in the range of $\mathrm{pH} 5.80-8.07$ on Jack Bean urease activity. J. Mol Catalysis B Enzymatic 6(1):75-81; 1999.

10. Larson, A. D.; Kallio, R. E. Purification and properties of microbial urease. J. Bacteriol. 68:67-73; 1953.

11. McLamore, E.; Morse, A.; Jackson, A.; Rainwater, K. Incorporation of a membrane-aerated bioreactor in a water recovery system (Paper \# 2004-01-2461). 34th International Conference on Environmental Systems (ICES), Colorado Springs, CO; 2004.

12. McLamore, E. Membrane-aerated bioreactors for the treatment of wastewater in long-term space flight. Thesis in Civil Engineering, Graduate Faculty of Texas Tech University; 2004.

13. Mobley, H. L. T.; Island, M. D.; Hausinger, R. P. Molecular biology of microbial ureases. Microbiol. Rev. September:451-480; 1995.

14. Mobley, H. T.; Hausinger, R. P. Microbial ureases: Significance, regulation, and molecular characterization. Microbiol. Rev. March:85-108; 1989.

15. Morse, A.; Jackson, A.; Rainwater, K.; Pickering, K. D. Membrane aerated reactors for the treatment of simulated wastewater. WEFTEC 2002, Chicago, IL, September 28October 3; 2002.

16. Morse, A.; Jackson, A.; Rainwater, K.; Pickering, K. Nitrification using a membrane-aerated biological reactor. 33rd International Conference on Environmental Systems (ICES), Bayshore Resort \& Marina, Vancouver, B.C., Canada, July 7-10; 2003.

17. Muirhead, D.; Rector, T.; Jackson, A.; Keister, H.; Morse, A.; Rainwater, K. Pickering, K. D. Performance of a small scale biological water recovery system (Paper \#2003-012557). 33rd International Conference on Environmental Systems (ICES); 2003.

18. Putnam, D. F. Composition and concentrative properties of human urine. Contract NAS 1-8954: Advanced Biotechnology Department, McDonnell Douglas Astronautics Company, Huntington Beach, CA; June 1970. 1989:5, 38-40.

19. Qin, Y.; Cabral, J. M. Kinetic studies of the urease-catalyzed hydrolysis of urea in a buffer-free system. Appl. Biochem. Biotechnol. 49(3):217-240; 1994.

20. Rector, T.; Jackson, W. A.; Rainwater, K.; Pickering, K. D. Determination of the fate and behavior of a commercial surfactant in a water recycle system (WRS) (Paper \# 200301-2558). Submitted to International Conference on Environmental Systems (ICES); 2003.

21. Schussel, L. J.; Atwater, J. E. A urease bioreactor for water reclamation aboard manned spacecraft. Chemosphere 30(5):985-994; 1995.

22. Sharvelle, S.; Banks, K.; Maloney, E. Surfactant biodegradation for application to advanced life support water recycling systems. 34th International Conference on Environmental Systems (ICES). Colorado Springs, CO; 2004.

23. Shaw, W. H. R.; Raval, D. V. The inhibition of urease by metal ions at $\mathrm{pH}$ 8.9. J. Am. Chem. Soc. 83:3184-3187; 1961.

24. Stegmayr, B.; Stegmayr, B. Crystal formation induced by uropathogenic bacteria. An in vitro study in human urine. Scand. J. Urol. Nephrol. 17(2):197-203; 1983.

25. Strayer, R. F.; Hummerick, M. P.; Garland, J. L.; Roberts, M. S.; Levine, L. H.; Krummis, V. Treatment of spacecraft wastewater in a submerged-membrane biological reactor. 33rd International Conference on Environmental Systems (ICES), Bayshore Resort \& Marina, Vancouver, B.C., Canada, July 7-10; 2003.

26. United States Environmental Protection Agency. Quality criteria for water. Report No. EPA 440/5-86-001, U.S. EPA, Office of Water Regulation and Standards, Washington, DC, May 1, 1986.

27. Verostko, C.; Carrier, C. Ersatz wastewater formulations for testing water recovery systems. 34th International Conference on Environmental Systems (ICES), Colorado Springs, CO; 2004.

28. Voet, D.; Voet, J.; Pratt, C. Fundamentals of biochemistry. New York: John Wiley \& Sons, Inc.; 1999.

29. Webb, P. M. D., ed. Bioastronautics data book. Washington, DC: NASA. SP-3006, National Aeronautics and Space Administration; 1989:215-218.

30. Wilsenach, J. A.; van Loosdrecht, M. C. M. Separate urine collection and treatment. Options for sustainable wastewater systems and mineral recovery (niet eerder opgenomen). Utrecht: STOWA, Stichting Toegepast Onderzoek Waterbeheer; 2002.

31. Wu, Q.; Bishop, P. L.; Keener, T. C. (2005). A strategy for controlling deposition of struvite in municipal wastewater treatment plants. Water Environ. Res. 77(2):199-207; 2005.

32. Wydeven, T.; Golub, M. A. Generation rates and chemical compositions of waste streams in a typical crewed space habitat. NASA Technical Memorandum \#102799. Moffett Field, CA: Ames Research Center; 1990. 